\title{
Towards Producer-Consumer Coopera- tion: Collective Learning in Alternative Food Networks as a Food Sovereignty Practice
}

The paper analyses collective learning strategies aimed at the transformation of food systems in the framework of food sovereignty, in the context of such key issues as environmental sustainability, socially just relations in diversified economy, and citizen participation in food systems governance. In particular, the author proposes to focus on the systematisation created by Colin R. Anderson, Chris Maughan and Michel P. Pimbert on the basis of their qualitative and action research undertaken for the purpose of developing the European Agroecology Knowledge Exchange Network (EAKEN). The network is part of the broader process of knowledge circulation led by the La Via Campesina movement, which has introduced the concept of food sovereignty into wider public debates. The main objective of EAKEN is to strengthen bottom-up learning strategies and informal education processes in the field of agroecology, which is defined through reference to sustainable farming practices and their recognised transformative potential. The author considers the pillars of transformative agroecology learning identified by the above-mentioned researchers in combination with various approaches in social movement 
learning and critical pedagogy. The analysis recognises that the evolving concept of food sovereignty covers both rural and urban fields of activity, emphasising the connections between producers, workers, consumers and social activists. Consequently, this paper contributes to the discussion on the educational practices present in alternative food networks (AFNs). As studies indicate, although new AFNs in Poland are often inspired by initiatives created in Western Europe and USA, they adopt forms that depend on the local context. The analysis of learning strategies associated with such networks, taking into account different forms of power relations, as well as emerging opportunities and constraints, allows areas for future research to be identified.

Keywords: collective learning, food sovereignty, agroecology, alternative food networks, critical education, transformative potential 


\section{Introduction}

The concept of transformative agroecology learning has its roots in a desire to change non-transparent and unsustainable food systems by focusing on ecology and human rights, strengthening local autonomy and democratising economic processes. With this in mind, Colin R. Anderson, Chris Maughan and Michel P. Pimbert (2019) conducted research among the activists of the global peasant movement, La Via Campesina, with the aim of contributing to the development of the European Agroecology Knowledge Exchange Network (EAKEN). The network brings together groups and organisations from different parts of Europe that are committed to implementing and supporting bottom-up learning strategies and informal education processes (Anderson, Maughan, and Pimbert 2019). Researchers have systematised the methods used within EAKEN and identified four pillars of the so-called transformative agroecological learning approach: "wisdom dialogues" (diálogo de saberes), "horizontal learning," "combining the practical and the political," and "building multi-scale social movement networks." These pillars determine the knowledge exchange processes that, in turn, shape communication patterns, as well as decision-making, and self-organisation processes within food activism (Anderson, Maughan, and Pimbert 2019). Their analysis encompasses the practices of food producers which are implemented "on the ground," but the agroecology strategies are linked to the political potential of food sovereignty, which refers to more abstract categories. Philip McMichael (2015, 193-194, 196) identifies food sovereignty as a counter-movement whose "second generation" phase combines both urban and rural initiatives at its core. The movement connects those who produce and consume, workers and activists, individuals and initiatives.

The article will use a literature review to provide a broader understanding of the concepts of both food sovereignty and agroecology. This may allow for a deeper insight into innovative forms of food politics and the processes of a social change affecting modern food systems. Following David Goodman, E. Melanie DuPuis and Michael Goodman (2014), I assume that the spheres of both production and consumption can be sources of political agency. At the same time, guided by cultural approaches, these spheres may relate to each other in relational terms, complement each other, and create networks of dependencies. My intention is to consider the producer-consumer relations that develop and transform through collective learning, in relation to the sociology of food and urban studies, as well as sociological and anthropological ana- 
lyses of the countryside and agriculture. The main aim of the article is to analyse collective learning as a practice of food sovereignty with a transformative potential. I position myself as a person involved in multi-directional knowledge exchange within food initiatives, including food cooperatives and food sovereignty projects, which, in a way, also introduces a transdisciplinary approach to the subject (Klein 2014).

The above-mentioned pillars of transformative agroecology learning will be juxtaposed with the objectives of alternative food networks (AFNs), in accordance with the EAKEN researchers' conclusion that the model they have developed could be adapted to other social movements. As it operates at different levels of the food system, it highlights the role of non-producers in the process of social transformation, reframing them as "more-than-consumers" (Anderson, Maughan, and Pimbert 2019, 544-545). Similarly, examples of documented activities from AFNs will be used to describe various educational practices on the basis of urban-rural relations. An analysis of these relations will be conducted to define their specific character in the context of Central and Eastern Europe. Since the transformative agroecology learning approach is rooted

The systemic changes advocated by many of contemporary rural movements concern not only food security, but also working conditions and social relations that are part of food production and distribution. Small-scale producers, including farmers and farm workers, are involved in reshaping the way food systems are organised and the processes concerning access to land, water and seeds. in popular education and agrarian movements, the paper will also contribute to the discussion on the objectives of critical pedagogy.

\section{Within the frameworks}

The birth of food sovereignty, both as an idea and a social movement, coincides with various historical processes and cannot be linked to a single geographical location - it remains a subject of negotiations and even a certain mythology (Edelman et al. 2014, 913-914). The mechanisms of the agri-food crises of the early 1980s, described by Walden Bello (2009) in relation to Mexico, China, African countries, and the Philippines, play a significant role in this context. As Bello notes, the reorientation of agricultural policy towards radical liberalisation has led to increased hunger, malnutrition and unemployment, as well as mass migration and protest movements. The systemic changes advocated by many of contemporary rural movements concern not only food security, but also working conditions and social relations that are part of food production and distribution. Small-scale producers, including farmers and farm workers, are involved in reshaping the way food systems are organised and the processes concerning access to land, water and seeds. These efforts are underpinned by the assumption that communities have the right to negotiate the relationship between global and local politics, 
and to co-produce the knowledge necessary for decision making (Bello 2009; Pimbert 2017b). In the food sovereignty discourse, the possession of certain rights (e.g. the right to food and to produce food, but also gender rights, or human rights) plays a significant role, taking the form of acts of social mobilisation and practices anchored in everyday experience (Edelman et al. 2014; McMichael 2015). It leads to the emergence of debates focusing on "what food is produced, where, how and by whom" (Edelman et al. 2014, 926). Reflections on these issues include visions of food security, sustainable ecosystems, social well-being, and different "ways of knowing." As Massimo De Angelis (2017, 285) comments (referring to Bina Agarwal):

The notion of food sovereignty has also evolved, and moved from a notion of state sovereignty (the demand that the state exercises its sovereignty with respect to food policies against the demands of the multinationals) to a notion of local and regional self-determination of farmers and consumers.

A flexible and evolving concept of food sovereignty cannot completely escape criticism. The influence of analyses of social movements and agrarian studies results in the formulation of such significant questions as:

Who is the sovereign in food sovereignty? (...) How much pluralism is acceptable in a food-sovereign society with respect to models of agricultural production, commerce and consumption? (...) If food sovereignty is founded on ,rights', how does it relate to the many other rights-oriented food movements that do not necessarily embrace the food sovereignty framework? (...) What impacts and implications does food sovereignty hold for transitions to a post-petroleum, post-growth and/or post-capitalist society? (Edelman et al. 2014, 913)

A critical perspective on food sovereignty may open up further discussions on the use of ambiguous concepts (such as "culturally appropriate" food) or the meanings attributed in social discourses to (transcending) regional and national borders (e.g. in the context of food-deficit regions) (Edelman et al. 2014). The complexity of the issue becomes more apparent when we take into consideration that the links between the idea of food sovereignty and the practice of agroecology are constantly reworked and updated, and that "an agroecology-centric position is but one of various possible interpretations of food sovereignty" (Edelman et al. 2014, 921). Agroecology itself has become the subject of competing definitions. Within the institutional framework (for instance, from the 
point of view of the Food and Agriculture Organisation of the United Nations), it has been understood "as a science and a set of agricultural practices” (Anderson, Maughan, and Pimbert 2019, 532), while for social movements, it represents "a way of life and a way of interacting with our surroundings [...] a process of individual and collective transformation, above and beyond specific agroecological techniques and practices" (ECVC Declaration on Agroecology). The second definition, supported by its social and ethical dimension, is based on such activities as setting up local seed houses, restoring plant species, or soil regeneration. In this context, building or renewing degraded ecosystems is based on observation, experimentation, and the selective use of new technologies, so that existing diversity (and diversified production) is not destroyed, and farming practices are not reduced to technological solutions (Bello 2009, 139-144). Thus, the implementation of agroecology includes in its scope social networks, environmental memory, social innovations and situated knowledge - the latter compiled from partial visions, embedded in the local context and based on alternative ways of valorisation. As "sustainable knowledge is often contextual, tacit, and proliferative" (Goodman, DuPuis, and Goodman 2014, 190), it is supported by both expertise and accumulated experience, using discursive and non-discursive forms.

\section{Acts of resistance and expressions of care}

In accordance with the work of Anna Nacher (2019, 34), for whom permaculture is an expression of the ethics of care, the three principles of permaculture - earthcare, peoplecare, and fair shares - serve as a manifestation of a "silent revolution," which is oriented towards maintenance rather than expansion. Less destructive agricultural practices that restore soil fertility, reduce fertilizers, and other sources of greenhouse gas emissions (e.g. related to deforestation), or ensure biodiversity, become part of a broader ecological discourse and constitute a response to climate change (Bańkowska 2019; Pimbert 2017a). It is worth noting that the consequences of climate change may be seen as reflections of the practices of the so-called Capitalocene era, which are related to the processes of unlimited capital accumulation and "business as usual." Jason W. Moore places capitalism in the "web of life" and highlights the relationship between power, profit, production and reproduction, which was formed even before the eighteenth-century industrial revolution (Moore $2015,2017)$. The theory of the Capitalocene replaces the anthropocen- 
tric assumptions about humanity's responsibility for the problems of the modern world with an analysis of the role of capital. It emphasises the commodification of environmental resources, human labour, food, and energy (Patel and Moore 2018). In this context, agroecological practices become expressions of care, as well as acts of resistance, manifested in everyday, tangible activities, and often associated with the space identified as "home." Such practices coexist with small-scale agriculture and occur against the background of enclosures of the commons and deagrarianisation processes in rural areas (Bollier 2014; Sadura, Murawska, and Włodarczyk 2017). They also overlap with the return of the "peasant issue" to the contemporary humanities, and the social debate (van der Ploeg 2018; Ryś 2015). Nowadays, the "new peasantry" is discussed in terms of relational categories and in the context of food activism.

\section{Urban-rural alliances}

Studying food sovereignty from the perspective of Polish domestic debates can be challenging. As Aleksandra Bilewicz $(2020,3)$ states: "[i]t is probably due to the dominance of the modernisation paradigm that the idea of food sovereignty is nearly absent from both academic and public discourse on agriculture and rural issues in Poland." In her work, Bilewicz analyses elements of the food sovereignty concept found in the assumptions and objectives of both contemporary rural protest movements and urban AFNs. She draws attention to the processes of combining the efforts of producers and consumers, but also highlights the significant discrepancies between their worldviews (Bilewicz 2020).

An alternative strategy for monitoring discourses on food sovereignty could consist in focusing on comparable analytical categories and related emancipatory practices. In this respect, it is worth taking into consideration the juxtaposition of contemporary food cooperatives with the pre-war movement of consumer cooperatives, which has been proposed by Bilewicz (2018). This juxtaposition allows Bilewicz to introduce the notion of countermovement and embeddedness, derived from Karl Polanyi's work, and to analyse food cooperatives in terms of mechanisms of self-protection against the domination of market forces and increasing social alienation.

A contemporary food cooperative can be regarded as a model example of AFN. It requires establishing direct contacts between consumers and food producers (including farmers) and organising group food pur-

Nowadays, the "new peasantry" is discussed in terms of relational categories and in the context of food activism. 
chases. Cooperatives have been developing in Poland since 2010 and "are referred to as one of the most important informal social movements to have arisen in the country over the past few years" (Bilewicz and Śpiewak 2019, 586). ${ }^{1}$ At the same time, cooperatives, which draw upon the idea of building active communities, usually opt for small-scale and informal organisations. The "shopping sessions", carried out once a week or once every two weeks in (usually temporary) spaces where farmers bring their produce, are the foundation of these initiatives. Volunteer members of cooperatives are the ones who are responsible for the coordination of all tasks, including the packing and dispensing of food. The Dobrze Food Cooperative is one of the entities that introduces new models of organisation, which at the same time provide greater stability. Registered as an association, it runs two shops in Warsaw, has employees, but also relies on the pre-agreed engagement of its members (Bilewicz 2018; Bilewicz and Śpiewak 2019; Pracownice i Pracownicy, n.d.).

Aside from the above-mentioned models, the AFNs field contains various socio-economic initiatives, some of which result from short food chains rooted in the history of Central and Eastern Europe, and some of which constitute new bottom-up initiatives originating in Western Europe and the United States. They include: farmers' markets, community supported agriculture (CSA), community and allotment gardens, farm-to-table box schemes, and local brands (Goszczyński et al. 2019; Rosol 2020). The AFNs landscape also encompasses organic farming and fair trade certificates, however, the links between these standardised systems and alternative economic practices of food sovereignty are seen as ambiguous (Bilewicz and Śpiewak 2019, 596; Edelman et al. 2014, 916). Although AFNs are economy-oriented, their aim is to transform the interconnections in food production and consumption, and to provide an alternative to conventional food distribution chains (Rosol 2020, 53). Numerous, scattered and diverse initiatives which fall within the scope of the AFNs are associated with the notions of food citizenship, the "quality turn" in food production and consumption, post-productivism, and environmental concerns (Bilewicz and Śpiewak 2015, 2019; Goszczyński, Wróblewski, and Wójtewicz 2018;

1 Currently, food cooperatives operate in various urban centres in Poland, among them Częstochowa, Płock, Wrocław, Lublin, Poznań and Kraków. Their informal nature makes it difficult to determine the exact number of members. In 2018 , it was estimated that approx. 1,100 people were active in such initiatives (Bilewicz and Śpiewak 2019). However, the research conducted in 2012-2015 indicates that the majority of cooperative members relied on the work of the most active people (Bilewicz 2018). 
Goszczyński et al. 2019; Rosol 2020). The alternative character of these networks is described in relation to product quality (e.g. its origin or production methods), distribution systems (networks and relations between producers and consumers), and alternative economic practices (Rosol 2020, 53, 56-58; see also Bilewicz and Śpiewak 2019; Goszczyński et al. 2019). The first two characteristics often attract the attention of the agri-food industry, due to their susceptibility to integration into commercial market strategies and discourses on organic, vegan, local, or regional food (Rosol 2020; see also Bilewicz and Śpiewak 2015). Meanwhile, Marit Rosol $(2020,59)$ notes that alternative (or non-capitalist) economic practices deserve special attention, highlighting their variety in the following enumeration:

(...) other forms of economic transactions (e.g., barter, donation, gifting, collecting, production for self-consumption), working practices (e.g., unpaid work of members, equal pay for all employees regardless of rank), forms of economic organization (e.g., cooperatives, collectives) and forms of financing (e.g., member loans, cooperative shares, crowdfunding, and others).

It should be noted, however, that not all AFNs represent food decommodification, and most of them "are not alternative in terms of their economic practices” (Rosol 2020, 59). Nevertheless, they are all considered to be oriented towards more than pure economic profitability. They maintain the viability of local food chains, support small-scale farming, encourage social integration, and are associated with reflexivity towards eating practices and environmental objectives (Bilewicz and Śpiewak 2019; Kopczyńska 2020; Rosol 2020).

The researchers' interest in the AFNs in Poland can be linked to a number of bottom-up initiatives that drive a growing engagement of city residents and formulate responses to global socio-economic crises. It is connected not only with the efforts to build a fair economy and implement systemic ecological solutions, but also with taking care of one's health and a desire to celebrate high-quality food (Bilewicz and Śpiewak $2015,2019)$. At the same time, the fact that small and medium-sized farms - and almost half of the agricultural land in Poland belongs to farms whose total area is equal to or smaller than twenty hectares (Baer-Nawrocka and Poczta 2018, 95) - are entering new food networks may be a sign that they are seeking some autonomy in the market, and partial independence from market fluctuations, especially in the face of crisis situations (van der Ploeg 2018). There are experts that claim that such initiatives as food cooperatives or community supported agriculture

It should be noted, however, that not all AFNs represent food decommodification, and most of them "are not alternative in terms of their economic practices" (Rosol 2020, 59). Nevertheless, they are all considered to be oriented towards more than pure economic profitability. 
will expand their scope, growing in line with the increasing importance of small farms and organic farming in Poland (Sadura, Murawska, and Włodarczyk 2017, 21, 33). On the other hand, the conclusions from the research on the attitudes of contemporary Polish farmers towards the concept of cooperatives indicate that the farmers' readiness to enter any such cooperation is relatively low. ${ }^{2}$ These reluctant attitudes are motivated by, among other things, the negative experiences of older generations who remember the post-war system with its forced collectivisation of agriculture and the state's political control of the cooperatives. Young farmers are more open to experimenting with various organisational forms and are interested in their economic potential. However, in general, most of the farmers had only a cursory stereotype-based knowledge of cooperatives. More importantly for this analysis, farmers pointed out that the development of cooperatives would require greater knowledge (professional advice) in the field of legal, organisational, or financial solutions, as well as the involvement of leaders who would have to initiate and coordinate such cooperation (Nowak and Gorlach 2015).

The subsequent sections of this article will focus on presenting the basic characteristics of AFNs in their less recognised dimension - in terms of the creation and circulation of knowledge. As indicated in the systematisation developed by Anderson, Maughan, and Pimbert, learning processes are not just the background for food activism. They may require contesting knowledges, rethinking beliefs and habits, and rewriting discourses (McFarlane 2016). As McFarlane $(2016,175)$ explains, "learning emerges as a distributed assemblage of people, materials and space that is often neither formal nor simply individual." Within AFNs, it can be assumed that learning processes and non-formal education can result in the development of tools that foster critical reflection.

\section{The importance of meetings}

The first pillar of the transformative agroecology learning approach was identified by Anderson, Maughan, and Pimbert (2019) as "wisdom dialogues" which embrace various encounters and social relations that strengthen pluralism. Such "wisdom dialogues" can be set in the context of hospitality (while also raising the issue of abandoning privileges in favour of coexistence; see: Majewska 2016), experienced by city dwellers

2 The research was conducted in 2013, among farmers who used the services of agricultural advisers (Nowak and Gorlach 2015). 
when they visit rural farms, as is often the case with food cooperatives or community-supported agriculture (Goszczyński et al. 2019; Rosol 2020). For example, members of the Dobrze Food Cooperative express their impressions of the visit to a vegetable farm with the following words: "this visit gave us the opportunity to learn more about vegetable cultivation methods and the approach towards soil, resources, health, and life" (Byliśmy z wizytą, n.d.). The meeting in question took place on a 10-hectare farm that combines elements of conventional and organic farming in the so-called integrated production. The Poznań Food Cooperative organised similar trips. The participants of one such trip helped with weeding, watered vegetables with nettle-based fertilizer, and collected tiliae flos. The farmers shared stories about their use of clay and straw for construction purposes, and milking farm animals (Poznańska Kooperatywa Spożywcza 2017).

The above-noted category of hospitality may also refer to relationship-building rituals, such as participation in a common feast prepared using produce from organic farms, or in a "coffee with a farmer," to which the Jurassic Food Cooperative invites the inhabitants of Częstochowa, by explaining:

(...) you will find out what an organic farm looks like today, whether it is still possible to cultivate the land in an environmentally friendly way, what methods are used by farmers on their farms, what they grow, and why (Jurajska Kooperatywa Spożywcza, n.d.).

It creates space for direct testimonies from people who are involved in farming - ones which go beyond the folksy narratives about work and life in the countryside. As Amanda Krzyworzeka (2015) notes, on the basis of her ethnographic research, work in agriculture does not have clearly defined working hours or remuneration, and the division of tasks often overlaps with family relations. Independence goes hand in hand with the need to maintain constant vigilance, and, sometimes, with a feeling of helplessness in the face of difficult-to-predict circumstances, e.g. dependence on weather and climate (see also Bolek 2020). At the same time, for most of the farmers studied by Krzyworzeka $(2015,145)$, work is a duty and an integral part of life.

"Wisdom dialogues" gain particular importance in intergenerational meetings and within uncompetitive spaces which bring together beginners and more experienced people (Anderson, Maughan, and Pimbert 2019). Learning processes among cooperatives' consumers include such issues as collective conflict solving, principles of participation, self-help, 
and self-governance. As developing skills related to non-hierarchical communication and collective decision-making is part of a group process, the role of a person who introduces new members, a mentor of sorts who is sensitive to changeable contexts, may prove to be crucial (Goszczyński et al. 2019; Rosol 2020). This issue was discussed during the 4th Congress of Cooperatives, organised in 2015 in Warsaw. The organizers note that the role of a leader is associated with competition, power, and prestige, and that it is often neglected in collectives which are focused on systemic changes. Yet, leadership could be redefined within a democratic collective to include cooperation, mutual understanding and empowerment (IV Zjazd Kooperatyw, n.d.).

This postulate may be applicable to the works of Paulo Freire, which introduce the notion of a humanist (and revolutionary) educator who participates in dialogic education. For Freire (2017), a dialogue should be "mediated by the world" (61) through "the present, existential, concrete situation, reflecting the aspirations of the people" (68), and in connection with their "preoccupations, doubts, hopes, and fears" (69). In this context, the act of "naming the world" is based on awakening consciousness and leads to the transformation of the world, to praxis. Dialogic education requires mutual trust and avoiding slogans or manipulation, and for Freire, a dialogue is an alternative to generating hierarchies (Freire 2013, 2017). However, it should be emphasised that Freire's theses on universal humanisation are challenged by analyses indicating that the author has neglected to consider the experience of women, partly by omitting the potential for change embedded in the private sphere, and also by approaching pedagogy in terms of struggle and revolution (Kopciewicz 2011, 34-37).

Finally, "wisdom dialogues" mean openness not only to relations between producers and non-producers, but also to cooperation with research institutions, universities or organisations, as well as the use of diverse definitions of ecology and just food systems. In this context, the Agro-eko-lab - a social innovation project created in 2018 as a result of the cooperation between the Dobrze Food Cooperative and the Agricultural School Complex in Jabłon - can be seen as an example of scaling up cooperative and agroecological ideas. This pilot project consisted of a series of training courses for students which focused on alternative ways of selling food and cultivating crops in accordance with agroecological principles. Students participated in a series of workshops and study visits to the farms which collaborate with cooperatives, an ecological market, and a cooperative-run shop. They had a chance to ask a number of questions, for example, on switching to organic farming 
or finding customers (TransferHUB, n.d.). One of the results of the project was the development of an experience-based model of education for young farmers. It had three thematic blocks: "Inspiration and knowledge," "Experience," and "Action." The scenarios of the proposed activities include such tasks as mapping the formal and informal sources of agricultural knowledge, the evaluation of selected on-line promotion strategies for farms, and identifying strengths and weaknesses of an agroecological farm (TransferHUB, n.d.).

"Wisdom dialogues" involves recognising different sustainable farming methods - e.g. organic, biodynamic, or based on permaculture (Anderson, Maughan, and Pimbert 2019, 537). However, it should be noted that there are models that do not fit this framework - "less-than-ideal" farms and agricultural landscapes (Edelman et al. 2014, 922). In a broader perspective, there is a need to conduct a dialogue with various groups of farmers, stakeholders and people interested in the subject (and Agro-eko-lab is a good example of such a dialogue). It may also be important for social movements to advocate for legal and organisational solutions supporting agroecology. This applies also to the financial mechanisms of the Common Agricultural Policy (including grants and subsidies), as well as state-run advisory programmes. With regard to the latter, according to the research on the transfer of knowledge in the organic farming system in Poland, agricultural advisory centres lack competent advisors specialising in this sector that would work on specific, practical solutions, and maintain in-depth relations with scientists (Śpiewak and Jasiński 2019). The possible involvement of social activists in agricultural policies does not mean giving up on the transformative nature of food sovereignty and agroecology. It can, however, be an expression of a critical self-reflection on the niche character of contemporary cooperatives and an attempt to create less dispersed regional networks of connections.

Another issue to consider is the standardisation of criteria - in the research carried out by Bilewicz and Śpiewak (2019) members of Polish food cooperatives demonstrated a certain level of distrust towards institutionalised organic certification schemes. Therefore, the analyses of the "quality turn" involve considering food as healthy or organic due to its links with individual producers. This means that the acquisition of knowledge about products and production methods takes place through personal connections (Bachórz 2018; Bilewicz and Śpiewak 2019; Goszczyński, Wróblewski, and Wójtewicz 2018). In the case of traditional urban food markets, trust in producers can determine the perception of the quality of the food they sell. What matters here is "purchasing 
products from particular people and in particular places" (Bachórz 2018, 104). As Bilewicz and Śpiewak $(2019,590)$ point out, direct relations between consumers and producers can result from both the pursuit of a "just economy" and the desire to maintain consumer control over food-related anxieties. "Natural" food is generally perceived in a positive way, but at the same time it is associated with a need for vigilance, verification, and risk assessment (Kopczyńska 2015). This contradiction highlights not only certain lack of trust at the personal level, but also - and perhaps most importantly - the insufficient transparency of global food systems (Kopczyńska and Bachórz 2018).

The ideas of horizontal learning do not exclude differences

in experience and diverse knowledges; they assume the equivalence of all voices in dialogic education.(...)

On the other hand, horizontal learning within AFNs has to be confronted with the issue of hierarchy.

\section{Farmer-to-farmer, peer-to-peer}

"Horizontal learning," the second pillar of the transformative agroecology learning approach proposed by Anderson, Maughan, and Pimbert (2019), refers to knowledge that comes directly from those who verify it through their work and then subsequently share it, on a farmer-to-farmer or peer-to-peer basis. The ideas of horizontal learning do not exclude differences in experience and diverse knowledges; they assume the equivalence of all voices in dialogic education. In principle, those who learn become trainers themselves. Often, the exchange of knowledge and experiences takes place among people who are facing similar challenges and taking part in a certain process collectively. On the other hand, horizontal learning within AFNs has to be confronted with the issue of hierarchy. The relationship between producer and consumer may be marked by tensions and barriers that result from negative stereotypes about the countryside or peasant farming - "considered "backward' and 'inefficient"' (Goszczyński et al. 2019, 2). Ewa Kopczyńska’s $(2017,650)$ research indicates that Polish AFNs are not free of such problems and that biases may affect the mutual trust in cooperation. The trajectories of industrial development and the dominance of a specific modernisation paradigm in public debates have played an essential role in shaping such attitudes (Bilewicz 2020; Edelman et al. 2014). Therefore, social movement learning and critical food systems education, as areas of study and research, involve recognising power relations, classand race-based divisions, and gender inequalities (Meek and Tarlau 2016). Supporting initiatives that go beyond the interests of a particular social class necessitates reflecting on the elitist character of consumption practices present in some of food cooperatives, as analysed by Bilewicz $(2015,2018)$. Social relations in these cooperatives functioned as 
a "selection mechanism," attracting people with similar (alternative) lifestyles or opinions. At the same time, access to healthier and "fair" food, corresponding to the aspirations of the middle class, became the priority. A further intriguing factor is the fluidity of spatial divisions, as exemplified by the "rural-rural divisions" - contemporary rural inhabitants are consumers as well, and can be both "peasants and proletarians" (Edelman et al. 2014, 918, 925).

It is worth emphasising that those initiatives and networks that developed in response to the shortage economy during the socialist period in Central and Eastern Europe also constituted alternatives to the dominant market distribution chains. Neighbourhood food exchanges which included, for example, sharing self-processed food, growing fruit and vegetables in urban allotment gardens, rural farmers supplying their family or friends with produce, and domestic cooking, constituted coping strategies, but also everyday grassroots, sustainable practices, which are still present in the post-socialist reality (Bachórz 2018; Bilewicz and Śpiewak 2019; Goszczyński et al. 2019). The "tacit knowledge" and "local know-how" (Kopczyńska 2020, 2) that emerge from such historically shaped activities, contribute to the creation or restoration of horizontal links. Therefore, while shopping, the significant moments are those when the consumer recalls vegetables with irregular shapes and rough skin, and associates fruit with defects with crops that are free of “improvements" (Kopczyńska 2017, 648). There are also consumers who judge the food offered at marketplaces "by looking at and smelling the items and by weighing up their trust of the seller" (Koopczyńska 2017, 650), and who have their own "paths, vendors, and rituals" (Kopczyńska 2017, 644). In her work on the traditional open-air food markets, Ewa Kopczyńska $(2017,648)$ concluded that this landscape of food practices includes a "prosumer model" of the customer. Many of Poland's inhabitants have gained experience in food production and cooking embedded in the country's agricultural history. The city dwellers interviewed by Agata Bachórz (2018) also referred to their own competences in the assessment of food products. To some extent, the prosumers, just like producers, have the ability to assess products in a fair manner. It can be stated that both those groups cultivate "informal or embodied knowledge, rooted in the past" (Bachórz 2018, 103), where " $[\mathrm{t}]$ he past is a resource not only in terms of evoking emotions, but also as an actual toolbox: a reservoir of skills and knowledge which could have been devaluated but are now returning to life" (Bachórz 2018, 106). Such a revival is also possible due to material resources - such as tools, recipes, and their ingredients (Goszczyński, Wróblewski, and 
Wójtewicz 2018). Knowledge anchored in the physical world, derived from everyday experience, allows the development of a language that emphasises the importance of the elements which are accidental, changeable, private and sometimes overlooked in social discourses (Freire 2013; Szkudlarek and Śliwerski 2010). The elements of the home distribution system - "the home itself, the freezer, bags, jars, and bottles in which food is kept and processed and which make it available to people" - are of great importance in this context (Kopczyńska 2020, 10). They mediate relations between individuals, and turn the consumer into "a reproducer of culture" (Goodman, DuPuis, and Goodman 2014, 43; Starego 2016).

\section{Empowerment and cooperation}

"Combining the practical and the political," the third pillar of the transformative agroecology learning approach, is based on the connection between individual experiences and socio-cultural reality (Anderson, Maughan, and Pimbert 2019). It includes involvement in the outside world, not just gaining knowledge about it (Starego 2016, 45). In the case of agroecological farming, combining the practical and the political leads to the empowerment of peasants - as land users (identified in historical and political terms) who are confronted with the "commodification of land, labour, genetic resources, and knowledges" (McMichael 2015, 199). In turn, the political dimension of AFNs corresponds with advocating for food sovereignty, and can be expressed through support of rural protests, as was the case with the Dobrze Food Cooperative and the Farmers Protest (Protest Rolników) in 2014 (Bilewicz 2020). Further political objectives relate to the idea of redistribution - ensuring broad access to healthy and affordable food. Finally, the blurred meaning of sustainability and the selective, competitive, and city-centric character of new urban environmental regimes require effective counterproposals (Edelman et al. 2014; Rosol, Béal, and Mössner 2017). Research indicates that local (grassroots) versions of sustainability are still present in the daily experience of traditional and family-oriented food networks in Poland, while newly emerging AFNs seem to be more compatible with global discourses on innovations and resilience (Kopczyńska 2020). Taking this into consideration, the critical learning process does not follow a specific scientific model, allowing instead for recognition of the political dimension of everyday experience, differences, and new forms of knowledge (Szkudlarek and Śliwerski 2010).

According to Anderson, Maughan, and Pimbert (2019), the collec- 
tive character of knowledge construction is an important element of "combining the practical and the political." Their concept refers to a "collective will" - to act, organise, and struggle for collective rights (Edelman et al. 2014, 925-926). In this context, knowledge may be incorporated into the "circuit of the commons." As De Angelis (2017) explains, the circuit of the commons includes both commodity and non-commodity production. "The non-commodity circuit represents the relational, cultural, and knowledge practices [...]" (De Angelis 2017, 196) which belong to the "commonwealth" of an "associated community," and are reproduced and developed through "commoning activity" (De Angelis 2017, 192-197). This, in turn, leads to the last pillar of the transformative agroecology learning approach described by Anderson, Maughan, and Pimbert (2019) as "building multi-scale social movement networks." In this context, "relational translocalism" emerges as a potential approach to shaping bottom-up networks at local, national, and international levels (McFarlane 2016, 177). Acting in a specific place, and with regard to local concerns, does not exclude reliance on non-local support and multi-level relationships, and coalitions created within the framework of food activism include inter-paradigm debates. Accordingly, the discourses on transformation and cooperation developed by AFNs overlap in their scope with debates on post-growth, which, in turn, raises the issue of the agricultural industry's dependence on fossil fuels (Rosol 2020). Researchers emphasise the correlation between "cheap food," subsidies and fossil energy, and point out that it will inevitably be transformed by climate change and its consequences (Edelman et al. 2014; Patel and Moore 2018). In contrast, as Kopczyńska (2017, 652) comments:

(...) cooperatives as collective consumer entities attempt to undermine the balance of power of the modern economic system - here specifically the food system - but they are also happy to make wider demands and speak with one voice with other associations of consumers, customers, recipients, residents, users, and other collective entities.

\section{Conclusions}

The analysis presented in this article constitutes a response to the "call to move from a farm-level focus to a whole food system approach to agroecology" (Anderson, Maughan, and Pimbert 2019, 544), which

Acting in a specific place, and with regard to local concerns, does not exclude reliance on non-local support and multi-level relationships, and coalitions created within the framework of food activism include inter-paradigm debates. 
gives rise to the need to update and expand the newly developed model in relation to other regions and social groups. As people studied by Anderson, Maughan and Pimbert $(2019,541,544)$ often found it difficult to identify specific learning methods within the above-described pillars, the systematisation has to be further deepened on the basis of specific, localised social practices. Within the context of the AFNs, the transformative potential of these practices is associated with diversified, situated and "sustainable" knowledge, which can be used to strengthen pluralism and non-hierarchical relationships, and become the source of empowerment and mobilisation. These assumptions are particular significant in the context of the minimal presence of food sovereignty ideas in Polish academic discourse and public debates. What is more, the research results indicate that the stereotypical images of agriculture and elite consumption patterns are reinforced by some of the Polish AFNs.

There is a need to continue the dialogue "between universal academic models and situated knowledge" (Goszczyński et al. 2019, 4) and reflect on the narratives that dominate within the sphere of AFNs. This includes a critical approach to one-dimensional visions of modernisation. It is becoming clear that recognition and redistribution are possible responses to the narrow scope of environmental policy and spatial justice demands, including fair urban-rural relations. The research reveals a diversity of strategies: from the "silent revolution" at the level of everyday farming practices, through vernacular ways of producing knowledge and transformative learning processes, to political advocacy and new social movements. In each of these areas, the relationship between individual experiences and the socio-cultural reality requires special attention - in order to better understand the process of empowerment defined not as the acquisition of critical competences by individuals, but as engagement in a collective dialogue and action in relation to specific external conditions, problems, or phenomena (Starego 2016).

The learning processes within AFNs deserve further analysis, especially in the case of those networks that have so far received less attention, such as farmers' markets or urban garden allotments. Analysing food consumption from a socio-political perspective means presenting the consumer's choice as something which exceeds the boundaries of passivity or illusion, and the food itself as more than an object of commodity fetishism. This approach assumes that the consumers' impact on the food system may go beyond cosmopolitan market niches. Contesting and developing knowledges, besides the right to be informed, is of key importance in this context, while advocacy for food sovereignty can support the scaling-up of cooperative and egroecological models (Good- 
man, DuPuis, and Goodman 2014, 33-38, 45-47). This is strongly related to the political agency of consumers, and thus to the need to explore more deeply the last two pillars of the transformative agroecological learning approach - "combining the practical and the political" and "building multi-scale social movement networks." Taking a critical look at the implementation of these assumptions by the AFNs may make it possible to overcome the city-centric framework that is ever-present in the discussions on the new social movements.

\section{References}

Anderson, Colin R., Chris Maughan, and Michel P. Pimbert. 2019. "Transformative agroecology learning in Europe: building consciousness, skills and collective capacity for food sovereignty." Agriculture and Human Values 36 (3): 531-547. https://doi.org/10.1007/s10460018-9894-0.

Angelis, Massimo De. 2017. Omnia Sunt Communia. On the Commons and the Trasformation to Postcapitalism. London: Zed Books.

Bachórz, Agata. 2018. "Hidden resources? Households' strategies for maintaining control over food: between continuity and discontinuity." Studia Humanistyczne AGH 17 (2): 97-109. https://doi. org/10.7494/human.2018.17.2.97.

Baer-Nawrocka, Agnieszka, and Walenty Poczta. 2018. "Rolnictwo polskie - przemiany i zróżnicowanie regionalne." In Polska wieś 2018. Raport o stanie wsi, edited by Jerzy Wilkin and Iwona Nurzyńska, 87-109. Warsaw: Wydawnictwo Naukowe Scholar.

Bańkowska, Katarzyna. 2019. "Przyroda jako dobro produkcyjne, dobro publiczne i wartość społeczna." In Ciagłość $i$ zmiana. Sto lat rozwoju polskiej wsi, edited by Maria Halamska, Monika Stanny, and Jerzy Wilkin, vol. 2, 803-836. Warsaw: Instytut Rozwoju Wsi i Rolnictwa PAN.

Bello, Walden. 2009. Food Wars. London, Brooklyn: Verso.

Bilewicz, Aleksandra. 2018. "A Path to a Countermovement? Forms of Integration in Polish Consumer Cooperatives." Praktyka Teoretyczna 27 (1): 133-167. https://doi.org/10.14746/prt.2018.1.6.

Bilewicz, Aleksandra M. 2020. "Beyond the Modernisation Paradigm: Elements of a Food Sovereignty Discourse in Farmer Protest Movements and Alternative Food Networks in Poland." Sociologia Ruralis, online first: 1-19. https://doi.org/10.1111/soru.12295. 
Bilewicz, Aleksandra and Ruta Śpiewak. 2015. "Enclaves of activism and taste. Consumer cooperatives in Poland as alternative food networks." Socio.hu Social Science Review 3: 145-166. https://doi. org/10.18030/socio.hu.2015en.145.

Bilewicz, Aleksandra and Ruta Śpiewak. 2019. "Beyond the »Northern« and "Southern " Divide. Food and Space in Polish Consumer Cooperatives." Eastern European Politics \& Societies and Cultures 33 (3): 579-602. https://doi.org/10.1177/0888325418806046.

Bolek, Maria. 2020. “Czas wolny na współczesnej wsi.” In Praca na wsi. Szkice etnologiczne, edited by Amanda Krzyworzeka, 198-220. Warsaw: Instytut Etnologii i Antropologii Kulturowej Uniwersytetu Warszawskiego \& Oficyna Naukowa.

Bollier, David. 2014. The Commons. Dobro wspólne dla każdego. Translated by Spółdzielnia Socjalna Faktoria. Zielonka: Faktoria.

ECVC Declaration on Agroecology. 2014. Accessed May 20, 2020. http://www.eurovia.org/wp-content/uploads/2016/03/ECVC-declaration-on-Agroecology-08-05-2014.pdf.

Edelman, Marc, Tony Weis, Amita Baviskar, Saturnino M. Borras Jr, Eric Holt-Giménez, Deniz Kandiyoti, and Wendy Wolford. 2014. "Introduction: critical perspectives on food sovereignty." Journal of Peasant Studies 41 (6): 911-931. https://doi.org/10.1080/0306615 0.2014 .963568$.

Freire, Paulo. 2013 [1974]. Education for Critical Consciousness. London, New York: Bloomsbury Academic.

Freire, Paulo. 2017 [1970]. Pedagogy of the Oppresed. Translated by Myra Bergman Ramos. London: Penguin Books.

Goodman, David, E. Melanie DuPuis, and Michael K. Goodman. 2014. Alternative Food Networks. Knowledge, Practice, and Politics. London, New York: Routledge.

Goszczyński, Wojciech, Michał Wróblewski, and Anna Wójtewicz. 2018. "Jakość w polskich alternatywnych sieciach żywnościowych. Analiza praktyk społecznych.” Studia Socjologiczne 228 (1): 143-170. https:// doi.org/10.24425/119090.

Goszczyński, Wojciech, Ruta Śpiewak, Aleksandra Bilewicz, and Michał Wróblewski. 2019. "Between Imitation and Embeddedness: Three Types of Polish Alternative Food Networks." Sustainability 11 (24): 7059 (1-19). https://doi.org/10.3390/su11247059.

Jurajska Kooperatywa Spożywcza. n.d. Accessed March 15, 2020. https://www.kooperatywa.czest.pl/w-kooperatywie-po-zdrowie.

Klein, Julie Thompson. 2014. "Discourses of transdisciplinarity: Looking Back to the Future.” Futures 63: 68-74. http://dx.doi.org/10.1016/j. 
futures.2014.08.008.

Kooperatywa Spożywcza Dobrze. n.d. "Byliśmy z wizytą u Majlertów." Accessed March 15, 2020. https://www.dobrze.waw.pl/bylismy-z-wizyta-u-majlertow/.

Kooperatywa Spożywcza Dobrze. n.d. "Pracownice i Pracownicy Kooperatywy." Accessed October 12, 2020. https://www.dobrze.waw.pl/ dla-czlonkowin/stanowiska-i-osoby/.

Kopciewicz, Lucyna. 2011. "Pedagogiczne teorie i feministyczne rewizje - John Dewey, Paulo Freire.” Forum Oświatowe 23 (2): 27-39.

Kopczyńska, Ewa. 2015. "Co to jest jedzenie naturalne? Socjonatura na targowisku." Studia Socjologiczne 219 (4): 181-203.

Kopczyńska, Ewa. 2017. "Economies of Acquaintances. Social Relations during Shopping at Food Markets and in Consumers' Food Cooperatives." East European Politics and Societies: and Cultures 31 (3): 637-658. https://doi.org/10.1177/0888325417710079.

Kopczyńska, Ewa. 2020. "Are There Local Versions of Sustainability? Food Networks in the Semi-Periphery." Sustainability 12 (7): 2845 (1-15). https://doi.org/10.3390/su12072845.

Kopczyńska, Ewa and Agata Bachórz. 2018. "Food fears, food distrust, and food exclusion in one postsocialist culture: and beyond". Studia Humanistyczne AGH 17 (2): 7-13. https://doi.org/10.7494/ human.2018.17.2.7.

Krzyworzeka, Amanda. 2015. Rolnicze strategie pracy i przetrwania. Studium z antropologii ekonomicznej. Warsaw: Wydawnictwa Uniwersytetu Warszawskiego.

Majewska, Ewa. 2016. "Gościnność, faszyzm, sfera publiczna. Kontrpubliczności podporządkowanych innych.” Opcje 104 (3): 40-47.

McFarlane, Colin. 2016. "Learning." In Urban Theory. New Critical Perspectives, edited by Mark Jayne and Kevin Ward, 172-182. Abingdon, Oxon; New York, NY: Routledge.

McMichael, Philip. 2015. "A comment on Henry Bernstein's way with peasants, and food sovereignty." The Journal of Peasant Studies 42 (1): 193-204. https://doi.org/10.1080/03066150.2014.936853.

Meek, David and Rebecca Tarlau. 2016. "Critical food systems education (CFSE): educating for food sovereignty." Agroecology and Sustainable Food Systems 40 (3): 237-260. https://doi.org/10.1080/216 83565.2015.1130764.

Moore, Jason W. 2015. Capitalism in the Web of Life. Ecology and the Accumulation of Capital. London, New York: Verso Books.

Moore, Jason W. 2017. “The Capitalocene, Part I: On the Nature and Origins of Our Ecological Crisis". Journal of Peasant Studies 44 (3): 
594-630. https://doi.org/10.1080/03066150.2016.1235036.

Nacher, Anna. 2019. "Obserwuj, reaguj, odkrywaj. Permakultura przeciw agrologistyce.” Prace Kulturoznawcze 23 (2-3): 27-40. https:// doi.org/10.19195/0860-6668.23.2-3.3.

Nowak, Piotr and Krzysztof Gorlach. 2015. "Rolnicy i spółdzielczość w Polsce: stary czy nowy ruch społeczny?” Wieś i Rolnictwo 166.1 (1.1): 131-154.

Patel, Raj and Jason W. Moore. 2018. History of the World in Seven Cheap Things. A Guide to Capitalism, Nature, and the Future of the Planet. London, New York: Verso Books.

Pimbert, Michel P. 2017a. "Constructing knowledge for food sovereignty, agroecology and biocultural diversity: An overview." In Food sovereignty, agroecology and biocultural diversity. Constructing and contesting knowledge, edited by Michel P. Pimbert, 1-56. London: Routledge.

Pimbert, Michel P. 2017b. "Democratizing knowledge and ways of knowing for food sovereignty, agroecology and biocultural diversity." In Food sovereignty, agroecology and biocultural diversity. Constructing and contesting knowledge, edited by Michel P. Pimbert, 259-321. London: Routledge.

Ploeg, Jan Douwe van der. 2018. The New Peasantries: Rural Development in Times of Globalization (Second Edition). London: Routledge.

Poznańska Kooperatywa Spożywcza. 2017. "II rowerowy rajd do Marszewa.” Accessed October 18, 2020. https://poznanskakooperatywa. $\mathrm{pl} / 2017 / 07 /$ rowerowy-rajd-do-marszewa/.

Rosol, Marit, Vincent Béal, and Samuel Mössner. 2017. "Greenest cities? The (post-)politics of new urban environmental regimes." Environment and Planning A 49 (8): 1710-1718. https://doi. org/10.1177/0308518X17714843.

Rosol, Marit. 2020. "On the Significance of Alternative Economic Practices: Reconceptualizing Alterity in Alternative Food Networks." Economic Geography 96 (1): 52-76. https://doi.org/10.1080/00130 095.2019 .1701430$.

Ryś, Paweł Wiktor. 2015. “»Zwrot plebejski« we współczesnej polskiej humanistyce i debacie publicznej." In Historia. Interpretacja. Reprezentacja, edited by Lech Mokrzecki, Mariusz Brodnicki, and Jacek Taraszkiewicz, vol. 3, 307-317. Gdańsk: Wydawnictwo Athenae Gedanenses.

Sadura, Przemysław, Katarzyna Murawska, and Zofia Włodarczyk. 2017. Wieś w Polsce 2017: diagnoza i prognoza. Warsaw: Fundacja Wspomagania Wsi.

Starego, Karolina. 2016. "Poza dyskurs kompetencji w edukacji kry- 
tycznej: »Trzeci termin« oraz Paula Freirego i Jacquesa Ranciere’a idea dialogu "zapośredniczonego«." Forum Oświatowe 28 (1): 33-53. Szkudlarek, Tomasz and Bogusław Śliwerski. 2010. Wyzwania pedagogiki krytycznej i antypedagogiki. Kraków: Oficyna Wydawnicza „Impuls”. Śpiewak, Ruta and Jakub Jasiński. 2019. "Knowledge Transfer in the Organic Farming System: the Role of Agricultural Advisory Service." Journal of Agribusiness and Rural Development 51 (1): 77-83. https:// doi.org/10.17306/J.JARD.2019.01111.

TransferHUB. n.d. "Agro-eko-lab." Accessed October 18, 2020. https:// transferhub.pl/poprzednia-edycja/innowacje-skalowane/agro-eko$-\mathrm{lab} /$.

IV Zjazd Kooperatyw (i nie tylko). n.d. "Opis sesji." Accessed October 14, 2020. https://zjazdkooperatyw2015.wordpress.com/program/ opis-sesji-2/. 
MAGDALENA POP ŁAWSKA - sociologist, PhD candidate at the Faculty of Sociology, at the Adam Mickiewicz University in Poznań. She has published on cultural education and animation. Her current research concerns social-ecological systems, social movements, critical pedagogy, and social circuits of knowledge. She is particularly interested in knowledge sharing within food-related initiatives.

\section{Address:}

Adam Mickiewicz University in Poznań

Faculty of Sociology

Szamarzewskiego 89

60-568 Poznań

email: magdalena.poplawska@amu.edu.pl

\section{Citation:}

Popławska, Magdalena. 2020. “Towards Producer-Consumer Cooperation: Collective Learning in Alternative Food Networks as a Food Sovereignty Practice." Praktyka Teoretyczna 4(38): 49-73.

DOI: $10.14746 /$ prt2020.4.3

Acknowledgements: I would like to thank anonymous reviewers for their insightful comments and suggestions.

Autor: Magdalena Popławska

Tytuł: W kierunku kooperacji producencko-konsumenckiej. Kolektywne uczenie się w alternatywnych sieciach żywności jako praktyka suwerenności żywnościowej

Abstrakt: W artykule analizowane są kolektywne strategie uczenia się, ukierunkowane na transformację systemów żywnościowych w odniesieniu do założeń suwerenności żywnościowej. Strategie te umieszczone zostały w kontekście takich zagadnień, jak równowaga przyrodnicza, sprawiedliwe relacje społeczne w obrębie zdywersyfikowanej gospodarki, a także aktywność obywatelska w ramach zarządzania systemami żywnościowymi. Autorka proponuje przyjrzenie się systematyzacji dokonanej przez Colina R. Andersona, Chrisa Maughana i Michela P. Pimberta, która jest rezultatem prowadzenia przez nich badań w działaniu oraz badań jakościowych, służących rozwijaniu Europejskiej Sieci Wymiany Wiedzy o Agroekologii [European Agroecology Knowledge Exchange Network - EAKEN]. Sieć ta jest związana z szerszym obiegiem wiedzy w ramach ruchu La Via Campesina, który z kolei wprowadził koncepcję suwerenności żywnościowej do globalnej debaty publicznej. Głównym założeniem EAKEN jest wzmacnianie oddolnych procesów uczenia się i edukacji nieformalnej w obszarze agroekologii, definiowanym w odniesieniu do zrównoważonych praktyk rolniczych oraz ich potencjału transformatywnego. Określone przez badaczy filary transformatywnego uczenia się agroekologii [transformative agroecology learning] 
zestawione zostały w tekście z różnymi podejściami wobec uczenia się w ruchach społecznych [social movement learning] oraz z założeniami pedagogiki krytycznej. Autorka uznaje, że ewoluująca idea suwerenności żywnościowej obejmuje zarówno wiejskie, jak i miejskie obszary aktywności. Podkreśla przy tym powiązania pomiędzy producentami, pracownicami, konsumentami i aktywistkami społecznymi, a także włącza się do dyskusji na temat praktyk edukacyjnych obecnych w alternatywnych sieciach żywności [Alternative Food Networks - AFNs]. Jak wynika z opracowań, pomimo iż nowo powstające w Polsce alternatywne sieci żywności często inspirują się rozwiązaniami stosowanymi w Europie Zachodniej i Stanach Zjednoczonych, przyjmują one postać zależną od lokalnego kontekstu. Analiza powiązanych z tymi sieciami strategii uczenia się uwzględnia różne formy relacji władzy oraz pojawiające się możliwości i utrudnienia. Określa ponadto potencjalne obszary dalszych badań.

Słowa kluczowe: edukacja nieformalna, suwerenność żywnościowa, agroekologia, alternatywne sieci żywności, pedagogika krytyczna, edukacja krytyczna, potencjał transformatywny 